\title{
Study protocol: DigiHand - the emergence of handwriting skills in digital classooms
}

\author{
Siv M. Gamlem, ${ }^{1 \star}$ Wenke M. Rogne, ${ }^{1}$ \\ Vibeke Rønneberg ${ }^{2}$ and Per Henning Uppstad ${ }^{2}$ \\ ${ }^{1}$ Volda University College and ${ }^{2}$ University of Stavanger
}

\begin{abstract}
This protocol article presents the project "DigiHand:The emergence of handwriting skills in digital classrooms." 1 The project is a longitudinal natural experiment investigating how the use of different writing tools influences students' handwriting and letter knowledge, word reading, spelling, written narrative composition and teacher-student interactions in Grades 1 and 2 (students aged 6 years in Grade 1). Participants are 33 schools ( $n=585$ students) representing three occurring conditions for learning writing skills in early years. Students in these conditions either (1) learn to write on a tablet while postponing handwriting, (2) learn both to handwrite and write on a tablet or (3) learn to handwrite. Effect analyses are conducted on four main domains of measures: (i) students' letter knowledge, spelling competence and word reading competence; (ii) students' handwriting fluency; (iii) students' ability to write narrative compositions; (iv) quality of teacher-student interactions. This protocol describes the background, design and pre- and outcome measures for the research project.
\end{abstract}

Keywords: Handwriting vs. digital writing; postponing handwriting; tablets; teacherstudent interactions; writing; word reading

Responsible editor: Guest editor: Åse Kari Hansen Wagner

Received: January, 2020; Accepted: May, 2020; Published: September, 2020

\section{Background}

In an age where classrooms are becoming increasingly digitized, knowledge of how digitalization influences learning is crucial. In Norway, the curriculum requires early grade classrooms to include both handwriting and digital tools in literacy instruction but does not specify how and to what extent (Ministry of Education and Research,

${ }^{1}$ This article was completed after the project was initiated.

^Correspondence: Siv M. Gamlem, e-mail: siv.therese.maseidvag.gamlem@hivolda.no 


\section{Gamlem, Rogne, Rønneberg $\mathcal{E}$ Uppstad}

2006, 2019). This might result in great variation in how handwriting and digital writing tools are used in first grade (students aged 6 years). Håland, Hoem and McTigue (2018) found that, in general, handwriting is most common in first grade in Norway. However, the implications of the digital shift in education are unknown (Kiefer \& Trumpp, 2012; Mangen et al., 2015; Mangen \& Velay, 2015). A pertinent question underpinning this study is in what ways the use of different writing tools might influence writing and word reading skills, and what quality of teacher-student interactions can be seen in classrooms during the two first years of schooling.

\section{Previous literature}

According to Wollscheid, Sjaastad and Tømte (2016), studies questioning the impact of using digital tools or pen and paper during the early years of schooling typically fall into one of three strands of theory: sociocultural perspectives, cognitivepsychological perspectives of writing acquisition and perspectives based on neuro-science and learning.

Sociocultural perspectives emphasize how literacy learning is embedded in the social, cultural and historical situation (Vygotsky, 1962). Researchers taking a sociocultural perspective (Barton, 2001) suggest that students may also benefit from getting their initial writing instruction on a keyboard/digital tablet (Genlott \& Grönlund, 2013). The rationale for this is that both handwriting and typing are mediating tools for literacy learning. Based on this assumed flexibility of mediation, socio-cultural perspectives frequently advocate approaching learning to read through writing (Wollscheid et al., 2016). Similarly, the way that kindergarteners intuitively interact with digital devices by typing or touching (Buchegger, 2013; Couse \& Chen, 2010) is taken as an argument in favor of writing training using typing to accelerate writing in young children or children with less developed sensory-motor skills (Castles et al., 2013, Doughty et al., 2013).

From a cognitive-psychological perspective, reading and writing are interconnected (Graham \& Herbert, 2011). Both involve knowledge of vocabulary (words, their internal morphology and their meanings in context) and syntax (sentence structure, complex sentences and usage). Moreover, both are complex processes that require reasoning and analytic ability (Miller et al., 2012). Reading is defined as the ability to decode written text quickly and accurately to comprehend what is read (Miller et al., 2012). Moreover, reading involves constructing mental representations that correspond to different levels, from more superficial to deeper levels of text comprehension (Kintsch \& van Dijk, 1978; van Dijk \& Kintsch, 1983). Writing is defined as a process involving working memory, text generation, transcription and executive functions (Berninger \& Winn, 2006; Graham et al., 1997). According to this view, text generation implies translating ideas into words, sentences and text. Thus, cognitive studies on writing focus on the processes involved in writing, the development of strategies and purpose (Graham \& Harris, 2018; Harris \& Graham, 2017). The low-level transcription skills, spelling and motor processes involved in 
producing spellings will necessarily be influenced by whether students write on a digital device or by hand. Handwriting is done with one hand, while two hands can be used for typing. Moreover, handwriting involves more complex motor skills than keyboarding. Further, handwriting allows writers to visually monitor their production (Mangen \& Veley, 2010; Wollscheid et al., 2016), while typing separates the produced letters from the motor area (i.e. the keyboard). Finally, when shaping the letters by hand, the writer must recall and then shape them accordingly. By contrast, when typing, the writer recognizes the letter and presses the key. In a small-scale study comparing students for whom handwriting was postponed until Grade 2 with students who learned to write with a pencil, the results showed that reading and writing skills were better in the group with postponed handwriting (Genlott \& Grönlund, 2013). Genlott and Grönlund (2013) found that first graders (7 years old, since in Sweden) in the test group wrote longer texts with better structure and clearer content and used more elaborate language. Thus, they suggested that writing on a keyboard might influence children's motivation to write - especially children who struggle with fine motor skills. However, more research with larger samples is needed.

Advocates of uniquely learning with pencil and paper often refer to studies in neuroscience (c.f. Mangen \& Velay, 2010), forming a niche in the embodied cognition paradigm. Such studies emphasize that handwriting activates areas of the brain that support visual recognition of letters (James, 2010; James \& Engelhardt, 2012), assuming that writing by hand leads to stronger offprints in the brain than does typing. In line with this, writing by hand is suggested to have consequences for letter recognition (Longcamp et al., 2005; Longcamp et al., 2008), the ease of learning to read (Dinehart \& Manfra, 2013) and writing words (Kiefer et al., 2015). Typically, however, studies within the embodied cognition paradigm are undertaken in highly controlled experimental settings, conducted over a short period and involve a relatively small number of participants (Kiefer et al., 2015; Longcamp et al., 2008). To our knowledge, few studies have investigated the modality effect in beginning writers. Based on the implications of the studies presented above, there is reason to believe that the use of different writing tools might influence students' letter knowledge, writing and word reading skills and quality of teacher-student interactions.

When teachers adopt a new writing modality (e.g. tablet, computer) in their practice, it has consequences for the teaching practice and likely also for teacher-student interactions. Sunde and Lundetræ (2019) identified a change in teachers' instruction regarding letter progression when students used tablets. Therefore, it appears reasonable to study teacher-student interactions in classrooms using a keyboard, postponing handwriting versus initial instruction using pen and paper, or a mixture of the two approaches. Teacher-student interactions can be studied as emotional support, classroom organization and instructional support in these conditions (Pianta et al., 2008). The DigiHand project focuses on how these different writing practices enable 


\section{Gamlem, Rogne, Rønneberg \& Uppstad}

different interaction patterns for classroom organization and quality in emotional and instructional support.

\section{The Norwegian school context}

In Norway, children enter the first grade in the year when they turn six years old. This applies to all children, including those with special needs. Children have a statutory right to attend their neighborhood school, and parents can apply to delay the start of school by one year if there is a need to do so. This applies to very few students (under $1 \%$ of the age group, c.f. Gabrielsen \& Lundetræ, 2017). In Norway, $96.2 \%$ of primary school students are enrolled in public (i.e. non-private) school. In first grade, $3.8 \%$ of students receive special needs education (2017-2018) and $7.1 \%$ receive special Norwegian training because they are non-native speakers (Norwegian Directorate for Education and Training, 2018).

The curriculum for Grades 1 and 2 is determined by the Ministry of Education and Research $(2006,2019)$, but schools have autonomy in choosing working methods and learning strategies. The curriculum also defines learning outcomes at the end of Grade 2, stating that students should be able to write and read at this point. Thus, the students should be able to write texts using both handwriting and a keyboard by the end of Grade 2. Moreover, students should be able to decode words and read and comprehend texts (Ministry of Education and Research, 2006, 2019).

\section{Research plan}

In the DigiHand project, we investigate how the use of different writing tools influences writing and word reading skills during the two first years of schooling. ${ }^{1}$ The aim of the project is to explore the effects of initial writing instruction using a keyboard, postponing handwriting versus initial instruction using pen and paper or a mixture of both approaches on (i) students' achievement in letter knowledge, spelling and word reading; (ii) students' handwriting fluency; (iii) students' ability to write narratives; (iv) the quality of teacher-student interactions.

\section{Research questions}

Using different methodological approaches, the aim is to address the following research questions:

- What are the effects of initial writing instruction using a keyboard, postponing handwriting versus initial instruction using pen and paper or a mixture of both approaches during the first two years of schooling?

- What characterizes the quality of teacher-student interactions in classrooms when using a keyboard, postponing handwriting versus initial instruction using pen and paper or a mixture of both approaches? 


\section{Design}

DigiHand is a natural, longitudinal experiment (see Figure 1). In the DigiHand project, teacher-initiated writing practices are important owing to the aim of studying the effects on writing and word reading skills that can be traced through different practices over the first two years of schooling.

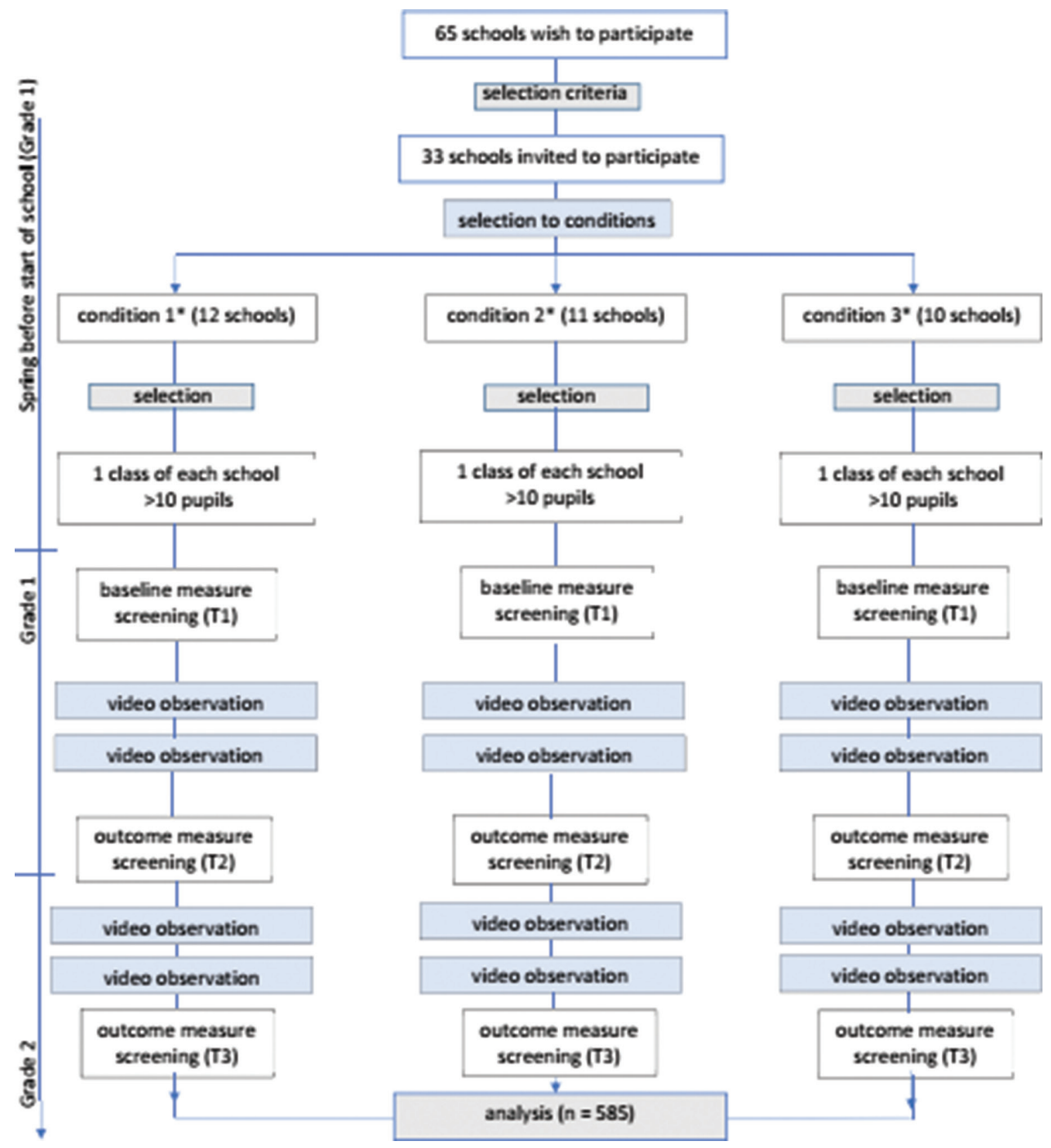

Figure 1. Design of the DigiHand project.

${ }^{*}$ Note. Condition $1=$ writing on keyboard + postponed handwriting. Condition $2=$ writing on keyboard + handwriting. Condition $3=$ handwriting. 


\section{Gamlem, Rogne, Rønneberg $\mathcal{E}$ Uppstad}

This project will involve studying three authentic conditions of learning to write. Schools representing the first condition teach writing on a keyboard and postpone handwriting until the second year. All students in this condition have a personal tablet and do their writing on the tablet keyboard. Schools in the second condition advocate the use of a personal tablet and handwriting. Schools in the third condition have students do their writing by hand in the first year. These students do not have personal tablets, but they might use the school's computers when working on some assignments (see Table 1).

Table 1. The conditions of writing modes in classrooms over two years.

\begin{tabular}{lccc}
\hline First year (Grade 1) & Condition 1 & Condition 2 & Condition 3 \\
\hline Writing on a keyboard (postpone handwriting) & $\mathrm{x}$ & $\mathrm{x}$ & $\mathrm{x}$ \\
Writing on a keyboard + handwriting & & & \\
Handwriting & & $\mathrm{x}$ & $\mathrm{x}$ \\
\hline Second year (Grade 2) & $\mathrm{x}$ & $\mathrm{x}$ & $\mathrm{x}$ \\
\hline Writing on a keyboard & $\mathrm{x}$ & & \\
Handwriting & & & \\
\hline
\end{tabular}

Thus, the research design forms a natural, longitudinal experiment in which different approaches to learning to write are studied. Natural experiments are often used to study situations in which controlled experimentation is not possible, such as when an exposure of interest cannot be practically or ethically assigned to research subjects (Cook \& Campbell, 1979). Since this is a natural experiment, participants must be selected from naturally occurring practices.

\section{Participants - Recruitment and eligibility}

Primary schools were recruited in the spring of 2018. Recruitment took place in two steps. In the first step, articles appeared in newspapers, on websites and on social media (Facebook, LinkedIn, Twitter) presenting the DigiHand project. These articles encouraged representatives of schools to contact the project or its research leader if they were interested in participating. In addition, contact was made with local schools to explain the project and conditions for participation. Consequently, representatives of several schools contacted the project leader and volunteered to participate. A total of 65 schools volunteered to participate, but only 33 schools met the selection criteria (see Figure 1). The selection was done according to the following specific criteria: (1) more than 10 students in each classroom to be enrolled in first grade in 2018, (2) use of Nynorsk as the main written Norwegian language in the school and (3) reported use of writing practices in first grade: initial writing instruction using a keyboard and postponing handwriting, both keyboard and handwriting or initial instruction using pen and paper. The last criterion was created to ensure that the schools were representing one of the three conditions (see Table 1). The selection of schools using Nynorsk as the main written language was meant to control 
for comparison, since there are two standard written norms in Norway and we want the groups of conditions to be equivalent when studying, for example, spelling.

Further, project invitations were sent to the principals of these 33 schools that met the criteria. In the second step, the project was presented to the parents and teachers of the incoming first-grade cohorts at meetings held at the respective schools. At these meetings, the researchers handed out information materials and consent forms. Schools with more than one first-grade class were informed that only one of these classes would be enrolled in the study. Therefore, if there was more than one firstgrade class at a school where teachers and parents had given consent, the participating class was chosen via a random draw. This selection of classes was conducted by the research leader, who had to perform several such draws.

A total of 606 students from these 33 schools were invited to participate, and $96.5 \%$ of parents consented to have their children participate in the study $(n=585)$. The students' mean age at the beginning of Grade 1 was 6.06 years. Moreover, boys constitute $51 \%$ of the sample and $12.1 \%$ are non-native speakers of Norwegian.

To obtain a sample that mirrors Norwegian public-school classrooms, all students are included in all study components. The same inclusion criteria are applied to L2 students (non-native speakers) and students with special needs. The only exception is students who are unable to participate in individual assessments due to severe disabilities. Thus, all students recruited to the study are included in longitudinal tracking in all three conditions. Calculation of the sample size was based on a sample of 5,700 Norwegian first graders from 300 classes in 150 schools (Solheim et al., 2017; Solheim et al., 2018). Classroom ICC on spelling was 0.07 . Based on our sample size calculation, a sample of 30 classrooms ( 10 classrooms in each condition) will allow us to detect effect sizes of 0.5 (p-value $0.05^{\star \star}$ ) with a power of $80 \%$.

For comparing between conditions, the 33 schools were controlled for results on the national test in reading for fifth graders. The mean value results on the national test in reading $(M=.49)$ showed that the participating schools placed in the three conditions formed equivalent groups. Further, to validate the reported writing practices in these schools, a questionnaire will be sent to the participating teachers twice during the project period - once per school year. The purpose of this is to control for the reported writing condition and to obtain deeper understanding of the writing practices. These questionnaires shall be handed out in the middle of Grade 1 and at the end of Grade 2. The questionnaire contains questions about classroom practices and background variables about the teacher (age, education, teaching experience, education in use of digital tools).

\section{Baseline measures and outcome measures}

All students will undergo testing for writing and word reading skills during first and second grades. As shown in Figure 1, the study includes three screening points: T1, $\mathrm{T} 2$ and $\mathrm{T} 3$. 


\section{Gamlem, Rogne, Rønneberg \& Uppstad}

\section{Baseline measures}

Baseline measures (T1) were collected at school entry in Grade 1. The data collection started after two weeks of schooling and was conducted within two weeks for all schools. Trained and certified testers $(n=17)$ conducted individual assessments of all students. The testers were supplied with a comprehensive written test manual to secure for inter-rater reliability. Student tests for the individual screening were administered on iPad Air2s using an app. The testers scored responses directly on the tablet. After these scores were recorded, they were uploaded to a secure database. The individual assessments were conducted in a quiet place within the students' local school and took about 20-25 minutes each to complete.

At baseline (T1), students were assessed in letter knowledge, phonological awareness, word reading, word writing, rapid automatized naming, vocabulary, word reading and short-term memory (see Table 2). These measures for literacy skills were developed and validated in order to compare development over the two years by research teams at the University of Stavanger (Lundetræ et al., 2017; Solheim et al., 2017; Solheim et al., 2018). For more information about these pre-measures at baseline (T1), see Table 2.

Table 2. Data collection and measures to test effects in DigiHand.

\begin{tabular}{|c|c|c|c|}
\hline Measure, scale & $\begin{array}{l}\text { Baseline } \\
\text { measures } \\
\quad(\mathrm{T} 1)\end{array}$ & $\begin{array}{c}\text { Outcome } \\
\text { measures } \\
(\mathbf{T} 2, \mathbf{T} 3)\end{array}$ & References \\
\hline Letter recognition & $\mathrm{x}$ & $\mathrm{x}$ & Solheim et al. (2018) \\
\hline Phonemic decoding efficiency & $\mathrm{x}$ & & Lundetræ et al. (2017); Torgesen et al. (1999) \\
\hline Phoneme isolation & $\mathrm{x}$ & & Solheim et al. (2018) \\
\hline Phoneme blending & $\mathrm{x}$ & & Lundetræ et al. (2017); Solheim et al. (2018) \\
\hline Word reading fluency & $\mathrm{x}$ & $\mathrm{x}$ & Lundetræ et al. (2017); Solheim et al. (2018) \\
\hline Word reading accuracy & $\mathrm{x}$ & $\mathrm{x}$ & Seymore et al. (2003) \\
\hline Vocabulary & $\mathrm{x}$ & $\mathrm{x}$ & Størksen et al. (2013) \\
\hline Spelling & $\mathrm{x}$ & $\mathrm{x}$ & Solheim et al. (2018) \\
\hline $\begin{array}{l}\text { Digit Span (WISC-III)/ } \\
\text { Short-term memory }\end{array}$ & $\mathrm{x}$ & $\mathrm{x}$ & Wechsler (1991) \\
\hline Grapho-motor skills & $\mathrm{x}$ & $\mathrm{x}$ & $\begin{array}{l}\text { An adapted version of Potsdam Grapho-Motor } \\
\text { Test Battery. } \\
\text { Nottbusch (Gerth et al. 2016) }\end{array}$ \\
\hline Copying fluency and accuracy & $\mathrm{x}$ & $\mathrm{x}$ & $\begin{array}{l}\text { Potsdam Grapho-Motor Test Battery Nottbusch } \\
\text { (Gerth et al., 2016) }\end{array}$ \\
\hline $\begin{array}{l}\text { Letter-to-dictation fluency and } \\
\text { accuracy }\end{array}$ & $\mathrm{x}$ & $\mathrm{x}$ & $\begin{array}{l}\text { Developed within the project: Fitjar et al. } \\
\text { (in progress) }\end{array}$ \\
\hline Teacher-Student interactions & $\mathrm{x}$ & $\mathrm{x}$ & Pianta et al. (2008) \\
\hline
\end{tabular}




\begin{tabular}{lccl}
\hline Measure, scale & $\begin{array}{c}\text { Baseline } \\
\text { measures } \\
\text { (T1) }\end{array}$ & $\begin{array}{c}\text { Outcome } \\
\text { measures } \\
\text { (T2, T3) }\end{array}$ & References \\
\hline $\begin{array}{l}\text { Written composition (text } \\
\text { length, space use accuracy, }\end{array}$ & & $\begin{array}{l}\text { Developed within the project: Spilling et al. } \\
\text { (in progress) }\end{array}$ \\
$\begin{array}{l}\text { spelling accuracy, use of sentence } \\
\text { terminators, advanced language, } \\
\text { syntactic complexity, vocabulary, } \\
\text { story grammar, narrative phases) }\end{array}$ & & & \\
\hline
\end{tabular}

In addition, at $\mathrm{T} 1$, handwriting process data for a subsample consisting of five classes from condition 1 and five classes from condition 3 was collected to be able to follow the students' handwriting development in two of the conditions. Three trained researchers are responsible for data collection. Data on handwriting processes are collected using WACOM digitizing tablets combined with open source software for logging handwriting, OpenHandwrite (Simpson et al., 2017).

Further, at baseline (T1), the students' parents answered a questionnaire relating to demographics, home literacy environment, the students' language background and familiar risk of reading difficulties. This is intended to control for background information about each student when analysing improvements in writing and word reading skills during the two first years of schooling.

To study teacher-student interactions, video recordings will be collected between baseline (T1) and outcome measure (T3) in classrooms for four cycles during the project period (see Figure 1) - one school day for each cycle. Classroom observations of teacher-student interactions for developing students' writing and word reading skills will be collected both in Grades 1 and 2. In these classrooms all the parents have given consent to conduct video recordings. The CLASS framework (Classroom Assessment Scoring System) will be used to study the quality of teacher-student interactions (Pianta et al., 2008). CLASS organizes student-teacher interactions into three domains: emotional support, classroom organization and instructional support. These three domains are composed of 10 dimensions (see Table 3).

Table 3. Overview of CLASS K-3 domains and dimensions (Pianta et al., 2008, p. 2).

\begin{tabular}{ll}
\hline Emotional support & Positive climate \\
& Negative climate \\
& Teacher sensitivity \\
Classroom organization & Regard for student perspectives \\
& Behaviour management \\
Instructional support & Productivity \\
& Instructional learning format \\
& Concept development \\
& Quality of feedback \\
& Language modelling \\
\hline
\end{tabular}




\section{Gamlem, Rogne, Rønneberg $\mathcal{E}$ Uppstad}

The CLASS K-3 manual (Pianta et al., 2008) is designed for studying teacherstudent interactions from kindergarten to Grade 3 and will be used in the current project. No observation system can accomplish all goals and focusing on any one activity or aspect of instruction means that others are likely to be lost (Harvey, 2006). Prioritizing the critical features of the observation tool is important, and the narrowness or breadth of the observations should be dictated by the overall purpose (Hill \& Grossman, 2013). CLASS K-3 is appropriate because of this study's focus on the quality of teacher-student interactions using different writing tools in primary school (Grades 1-2). The quality of teacher-student interactions on each dimension in CLASS is measured on a seven-point Likert-type scale $(1-2=$ low range, $3-5=$ medium range, $6-7=$ high range). These scores are based on the descriptions provided in the CLASS manual (Pianta et al., 2008). Using a validated instrument might allow for comparisons across previous studies (e.g. Pakarinen et al., 2017) and contribute more knowledge of interactions in different conditions.

\section{Outcome measures}

Outcome measures (T2 and T3) consist of students' scores on writing and word reading skills. These include measures of handwriting accuracy, written composition and handwriting fluency for the same subsample as at T1. In addition, a manual for scoring quality of teacher-student interactions are included (see Table 2). Repeated measures are administered at both data collection points. Since students' writing and reading skills develop rapidly over the first two years of education, new measures for spelling are included at T2 and T3 to avoid ceiling effects.

To assess students' handwriting fluency, handwriting process data will be collected at T2 and T3 for a subsample of 10 classes. To achieve the ambitious aims of the study, quality evaluations of letters and measures of automaticity of letter shaping are required. A coding manual for letters has been developed to accurately identify correctly shaped letter parts (Fitjar et al., in progress). Key measures for analysing handwriting fluency are temporal, kinematic and dynamic (see Table 4).

Table 4. Measures of handwriting fluency

\begin{tabular}{ll}
\hline Temporal & Total movement time for shaping the actual letter (word) \\
& Stop duration \\
Kinematic & Speed \\
& Number of inversions of velocity (NIV) \\
Dynamic & Number of pen lifts \\
\hline
\end{tabular}

Students' ability to write compositions will be assessed at different time points. Two texts - one written by hand and one typed - were collected from 140 students in the first term of Grade 1. In addition, a subsample of 180 students will be assessed at 
five time points during Grade 1. Finally, all 585 students will write two texts at two time points in Grade 2. All texts will be written narratives. The study will contribute to research on beginning writing by investigating how different writing media handwriting and typing - affect the narrative composition performance of beginning writers. The analyses of written outcomes involve a wide range of linguistic measures. Outcome variables include text length, space use accuracy, spelling accuracy, use of sentence terminators and syntactic complexity.

The researchers have developed a measure of advanced vocabulary (Spilling et al., in progress). In addition, texts will be assessed for story grammar (Labov \& Waletsky, 1967) and adaptations of narrative phases (Martin \& Rose, 2008).

\section{Analysis plan}

The effects of reading and writing development will be assessed using regression models (ANOVA). We will also investigate differential effects across performance on baseline measures - namely, parental socio-economic status, minority background, special needs education and gender.

Effects on text quality measures will be assessed using mixed effects regression models, evaluated using the $\mathrm{R}$ lme 4 package (Bates et al., 2013). Structural equation modelling using the Iavaan package in R (Rosseel, 2012), will be used to measure relationships between the various handwriting measures and letter knowledge, phonemic awareness and reading.

The observation data of the three conditions will be used to study the quality of teacher-student interactions in classrooms. These observations will be analysed using the CLASS K-3 manual (Pianta et al., 2008). The data analysis will consist of descriptive statistics of quality of teacher-student interactions with emphasis on the mean, minimum and maximum scores, standard deviation, standard error and skewness and kurtosis values. Subsequently, Pearson's $r$ product-moment correlations will be calculated to check for significant relationships between the dimensions in CLASS K-3. In addition, an analysis will be conducted to map possible differences in the quality of teacher-pupil interactions in classes that use different writing tools (Levene's Test for Equality of Variance).

\section{Personnel}

The research team consists of senior and junior researchers as well as research assistants.

\section{Principal investigators}

Associate Professor Wenke Mork Rogne, Volda University College

Professor Siv M. Gamlem, Volda University College

Professor Per Henning Uppstad, Norwegian Reading Centre, University of Stavanger 


\section{Gamlem, Rogne, Rønneberg $\mathcal{E}$ Uppstad}

Associate Professor Vibeke Rønneberg, Norwegian Reading Centre, University of Stavanger

Associate Professor Gudrun Kløve Juuhl, Volda University College

\section{PhD candidates (alphabetically listed)}

Doctoral Research Fellow Camilla Fitjar, University of Stavanger

Doctoral Research Fellow Eivor Finset Spilling, Volda University College

Doctoral Research Fellow Liv Kristin Bjørlykke Øvereng, Volda University College

\section{Co-investigators (alphabetically listed)}

Associate Professor Pernille Fiskerstrand, Volda University College

Senior Lecturer Birgitte Fondevik, Volda University College

Associate Professor Liv Ingrid Aske Håberg, Volda University College

Lecturer Randi Ottesen, Volda University College

Lecturer Marit Wadsten, Volda University College

Lecturer/Research Assistant Lina Rebekka Kobberstad, Volda University College

Research assistants (alphabetically listed)

Research Assistant Solgun Nedreberg, Volda University College

Research Assistant Ingrid Rønneberg, University of Stavanger

Research Assistant Lillian Fitjar Dahl, University of Stavanger

\section{Work plan and timeline}

The DigiHand project is scheduled from June 2018 until December 2021. Table 5 presents the work plan and timeline of the project.

Table 5. Work plan and timeline of the project

\begin{tabular}{|c|c|c|}
\hline Task & Date/deadline & Responsibility \\
\hline $\begin{array}{l}\text { Recruit schools, identify and } \\
\text { randomize into conditions }\end{array}$ & June-August 2018 & $\begin{array}{l}\text { Wenke Mork Rogne, Siv. M. } \\
\text { Gamlem and Vibeke Rønneberg }\end{array}$ \\
\hline $\begin{array}{l}\text { Develop use of DigiHand app } \\
\text { on tablet-based solutions for } \\
\text { assessment }\end{array}$ & Spring 2018 & $\begin{array}{l}\text { NettOp, University of Stavanger, } \\
\text { Per Henning Uppstad and Kjersti } \\
\text { Lundetræ }\end{array}$ \\
\hline $\begin{array}{l}\text { Develop survey measures } \\
\text { and assess instruments } \\
\text { (questionnaires) }\end{array}$ & January 2018-May 2020 & $\begin{array}{l}\text { Wenke M. Rogne, Siv M. } \\
\text { Gamlem, Vibeke Rønneberg and } \\
\text { Per Henning Uppstad }\end{array}$ \\
\hline Train testers for tablet assessment & $\begin{array}{l}\text { August 2018, April 2019, April } \\
2020\end{array}$ & Per Henning Uppstad \\
\hline $\begin{array}{l}\text { Collect pre-test data in schools } \\
\text { (T1) }\end{array}$ & September 2018 & $\begin{array}{l}\text { Wenke M. Rogne, Siv M. } \\
\text { Gamlem and Vibeke Rønneberg }\end{array}$ \\
\hline
\end{tabular}




\begin{tabular}{|c|c|c|}
\hline Task & Date/deadline & Responsibility \\
\hline $\begin{array}{l}\text { Administer questionnaire - } \\
\text { parents }\end{array}$ & October 2018 & $\begin{array}{l}\text { Wenke M. Rogne, Siv M. } \\
\text { Gamlem and Vibeke Rønneberg }\end{array}$ \\
\hline Train testers for video observation & September 2018 & Siv M. Gamlem \\
\hline $\begin{array}{l}\text { Classroom observation - collect } \\
\text { video recordings }\end{array}$ & $\begin{array}{l}\text { November 2018, March 2019, } \\
\text { November 2019, April } 2020\end{array}$ & $\begin{array}{l}\text { Siv M. Gamlem and Wenke M. } \\
\text { Rogne }\end{array}$ \\
\hline $\begin{array}{l}\text { Administer questionnaire - } \\
\text { teachers }\end{array}$ & February 2019, April 2020 & $\begin{array}{l}\text { Wenke M. Rogne, Siv M. } \\
\text { Gamlem and Vibeke Rønneberg }\end{array}$ \\
\hline $\begin{array}{l}\text { Collect post-test data in schools } \\
(\mathrm{T} 2, \mathrm{~T} 3)\end{array}$ & May 2019, May 2020 & $\begin{array}{l}\text { Wenke M. Rogne, Siv M. } \\
\text { Gamlem and Vibeke Rønneberg }\end{array}$ \\
\hline \\
\hline $\begin{array}{l}\text { including the following: } \\
\text { a) Analyse effects of different } \\
\text { conditions: handwriting/ } \\
\text { digital writing/ability to write } \\
\text { compositions }\end{array}$ & $2018-2021$ & $\begin{array}{l}\text { a) Camilla Fitjar, Eivor Finset } \\
\text { Spilling, Vibeke Rønneberg, } \\
\text { Wenke M. Rogne and Mark } \\
\text { Torrance }\end{array}$ \\
\hline $\begin{array}{l}\text { b) Analyse quality of teacher- } \\
\text { student interactions in different } \\
\text { conditions }\end{array}$ & $2019-2021$ & $\begin{array}{l}\text { b) Liv Kristin B. Øvereng, Siv } \\
\text { M. Gamlem and Per Henning } \\
\text { Uppstad }\end{array}$ \\
\hline \multicolumn{3}{|c|}{ Disseminate project findings: } \\
\hline \multicolumn{2}{|c|}{$\begin{array}{l}\text { a) Participating schools will be provided with project findings during } \\
\text { and at the end of the project }\end{array}$} & $\begin{array}{l}\text { a) Wenke M. Rogne, Siv M. } \\
\text { Gamlem, Vibeke Rønneberg and } \\
\text { Per Henning Uppstad }\end{array}$ \\
\hline \multicolumn{2}{|l|}{ b) Peer-reviewed publications } & $\begin{array}{l}\text { b) and c) Wenke M. Rogne, Siv } \\
\text { M. Gamlem, Vibeke Rønneberg, } \\
\text { Per Henning Uppstad, Camilla }\end{array}$ \\
\hline \multicolumn{2}{|c|}{$\begin{array}{l}\text { c) Conference presentations: the project staff will present data at } \\
\text { international conferences }\end{array}$} & $\begin{array}{l}\text { Fitjar, Liv Kristin Øvereng, Eivor } \\
\text { F. Spilling, Gudrun Kløve Juuhl } \\
\text { and Mark Torrance }\end{array}$ \\
\hline \multicolumn{2}{|c|}{$\begin{array}{l}\text { d) Provide project findings via the infrastructure of Reading Centre } \\
\text { at Stavanger (UIS) and the Centre of New Norwegian at Volda } \\
\text { University College (VUC) for dissemination to schools. }\end{array}$} & $\begin{array}{l}\text { d) Kjersti Lundetræ (UIS) } \\
\text { Liv Kristin Øvereng and Marit } \\
\text { Wadsten (VUC) }\end{array}$ \\
\hline
\end{tabular}

\section{Ethics}

The DigiHand project follows the guidelines outlined by the Norwegian National Research Ethics Committees and the Norwegian Centre for Research Data (NSD). Approval from the NSD was obtained before data collection began. Consent for participation from teachers and parents was obtained. Due to the students' age, their parents had to provide consent for their children to participate in the study. Regarding ethical regulations, all participants are promised anonymity and confidentiality.

For students to obtain mastery and self-efficacy beliefs during data collection, the measures of literacy skills obtained by the tablet were automatically terminated after 


\section{Gamlem, Rogne, Rønneberg $\mathcal{E}$ Uppstad}

two subsequent errors at T1. Further, at T2, assignments as "reading words" were stopped at six subsequent errors.

Video recordings of lessons will be used strictly for analysis purposes by the research team. Video data will be handled in accordance with NSD. As the participants' anonymity is ensured, video recordings cannot be shared or used for purposes other than analyses.

At the end of the project, the findings will be communicated to the teachers and participating schools.

\section{Summary and implications}

The project's aim is to contribute to the building of national competency by providing new knowledge on a timely issue in early literacy instruction: the emergence of handwriting in digital classrooms in Norway. The approach is innovative by addressing the actual outcomes of three existing practices. To date, comparisons of writing by hand and writing on a keyboard have mainly been conducted in lab settings by means of experimental studies on which approach the brain prefers, and these studies have often been conducted with older students (adults) using isolated tasks. We apply Occam's razor in claiming that there is a strong case for evaluating this kind of pedagogical practice with high ecological validity. The project has potential theoretical implications for how we conceive of access to written script, text and text culture.

\section{Author biography}

Siv M. Gamlem, Professor of Education at Volda University College, Norway. She holds a phd in feedback to support learning, with research interests in learning processes, assessment, and teaching.

Wenke Mork Rogne, Associate Professor at the Teacher Training in Volda University College. Main reseach interests are Students Reading and Writing Comprehension, Development and Assessment.

Vibeke Rønneberg is associate professor at the Norwegian Reading Centre, University of Stavanger. She holds a PhD in linguistics, with research interests in writing processes, handwriting and educational assessment.

Per Henning Uppstad, Professor of special needs education at the Norwegian Reading Centre, University of Stavanger, and Professor II at Volda University College. He holds a $\mathrm{PhD}$ in general linguistics, with research interests in technology enhanced learning, reading and writing, educational assessment and early literacy intervention. 


\section{Funding and Acknowledgements}

The DigiHand project (2018-2021) is funded by the Research Council of Norway, research program "FINNUT", grant number 273422.

We are grateful to Professor Oddny Solheim (University of Stavanger) and Professor Kjersti Lundetræ (University of Stavanger) for their support in designing this study.

\section{References}

Bates, D., Maechler, M., Bolker, B., \& Walker, S. (2013). lme4: Linear mixed-effects models using Eigen and S4. R package version 1.0-5.

Barton, D. (2001). Directions for literacy research: Analysing language and social practices in at textually mediated world. Language and Education, 15(2-3), 92-104. https://doi.org/10.1080/09500780108666803

Berninger, V. W., \& Winn, W. D. (2006). Implications of Advancements in Brain Research and Technology for Writing Development, Writing Instruction, and Educational Evolution. In C. A. MacArthur, S. Graham, \& J. Fitzgerald (Eds.), Handbook of writing research (p. 96-114). The Guilford Press.

Buchegger, B. (2013). Unterrichtsmaterial Safer im Kindergarten. ÖIAT Österreichisches Institut für angewandte Telekommunikation.

Castles, A., McLean, G. M., Bavin, E., Bretherton, L., Carlin, J., Prior, M., Ukoumunne, O., Wake, M., \& Reilly, S. (2013). Computer use and letter knowledge. Fournal of Pediatric Child Health, 49, 193-198. https://doi. org/10.1111/jpc. 12126

Cook, T. D., \& Campbell, D. T. (1979). Quasi-experimentation: Design E analysis issues in field settings. Houghton Mifflin.

Couse, L. J., \& Chen, D. W. (2010). A tablet computer for young children? Exploring its viability for early childhood education. Fournal of Research on Technology in Education, 43(1), 75-98. https://doi.org/10.1080/ 15391523.2010 .10782562

Dinehart, L., \& Manfra, L. (2013) Associations between low-income children's fine motor skills in preschool and academic performance in second grade. Early Education and Development, 24(2), 138-61. https://doi. org/10.1080/10409289.2011.636729.

Doughty, T. T., Bouck, E. C., Bassette, L., Szwed, K., \& Flanagan, S. (2013). Spelling on the fly: Investigating a pentop computer to improve the spelling skills of three elementary students with disabilities. Assistive Technology, 25(3), 166-175. https://doi.org/10.1080/10400435.2012.743491

Fitjar, C., Rønneberg, V., Torrance, M., \& Nottbusch, G. (in progress). Relative contributions of pen control and letter knowledge to letter writing fluency.

Gabrielsen, E. \& Lundetræ, K. (2017). Indikerer de norske PIRLS-resultatene et behov for å justere retningslinjene for skolestartsalder? In E. Gabrielsen (Ed.), Klar framgang! Leseferdighet på 4. og 5. trinn $i$ et femtensårsperspektiv (pp. 204-221). Universitetsforlaget.

Genlott, A., \& Grönlund, Å. (2013). Improving literacy skills through learning reading by writing: The iWTR method presented and tested. Computers $\mathcal{E}$ Education, 67, 98-104. http://dx.doi.org/10.1080/17439884. 2012.756518

Gerth, S., Klassert, A., Dolk, T., Fliesser, M., Fischer, M. H., Nottbusch, G., \& Festman, J. (2016, September 12). Is handwriting performance affected by the writing surface? Comparing preschoolers', second graders', and adults' writing performance on a tablet vs. paper. Frontier Psychology. https://doi.org/10.3389/ fpsyg.2016.01308

Graham, S., Berninger, V.W, Abbott, R. D., Abbott, S. P., \&Whitaker, D. (1997). Role of mechanics in composing of elementary school students: A new methodological approach. Fournal of Educational Psychology, 89(1), 170-182. https://doi.org/10.1037/0022-0663.89.1.170

Graham, S., \& Harris, K. R. (2018). Evidence-based practices in writing. In S. Graham, C. A. MacArthur, \& M. Herbert (Eds.), Best practices in writing instruction (pp. 3-29). The Guilford Press.

Graham, S., \& Herbert, M. (2011). Writing-to-read: A meta-analysis of the impact of writing and writing instruction on reading. Harvard Educational Review, 81, 710-744. https://doi.org/10.17763/haer.81.4. t2k0m13756113566 


\section{Gamlem, Rogne, Rønneberg $\mathcal{E}$ Uppstad}

Harris, K. R., \& Graham, S. (2017). Self-regulated strategy development:Theoretical bases, critical instructional elements, and future research. In R. F. Redondo, K. R. Harris, \& M. Braaksma (Eds.), Design principles for teaching effective writing (pp. 119-151). Brill. https://doi.org/10.1163/9789004270480_007

Harvey, P. (2006). Improving teaching observation practice in the learning and skills sector: A literature review. City College Norwich.

Hill, H. C., \& Grossman, P. (2013). Learning from teacher observations: Challenges and opportunities posed by new teacher evaluation systems. Harvard Educational Review. https://cepr.harvard.edu/publications/learningteacher-observations-challenges-and-opportunities-posed-new-teacher

Håland, A., Hoem, T. F., \& McTigue, E. M. (2018). Writing in first grade: The quantity and quality of practices in Norwegian classrooms. Early Childhood Education fournal, 47, 63-74. https://doi.org/10.1007/s10643018-0908-8

James, K. H. (2010). Sensori-motor experience leads to changes in visual processing in the developing brain. Developmental Science, 13(2), 279-288. https://doi.org/10.1111/j.1467-7687.2009.00883.x

James, K. H., \& Engelhardt, L. E. (2012). The effects of handwriting experience on functional brain development in pre-literate children. Trends in Neuroscience and Education, 1, 32-42. https://doi.org/10.1016/j.tine.2012. 08.001

Kiefer, M., \& Trumpp, N. (2012). Embodiment theory and education:The foundations of cognition in perception and action. Trends in Neuroscience and Education, 1, 15-20._http://doi/org/10.1016/j.tine.2012.07.002

Kiefer, M., Schuler, S., Mayer, C., Trumpp, N. M., Hille, K., \& Sachse S. (2015). Handwriting or typewriting? The influence of pen- or keyboard-based writing training on reading and writing performance in preschool children. Advances in Cognitive Psychology, 11(4), 136-146. https://doi.org/10.5709/acp-0178-7

Kintsch, W., \& van Dijk, T. A. (1978). Toward a model of text comprehension and production. Psychological Review, 95(2), 163-182. https://doi.org/10.1037/0033-295X.85.5.363

Labov, W., \& Waletzky, J. (1967). Narrative analysis: Oral versions of personal experience. In J. Helm (Ed.), Essays on the verbal and visual arts. University of Washington Press.

Longcamp, M., Boucard, C., Gilhodes J-C, C., Anton J. L., Roth M., Nazarian B., \& Velay, J. (2008). Learning through hand- or typewriting influences visual recognition of new graphic shapes: Behavioral and functional imaging evidence. Fournal of Cognitive Neuroscience, 20(5), 802-815. https://doi.org/10.1037/0033-295X. 85.5.363

Longcamp, M., Zerbato-Poudou, M. T. \& Velay, J. L. (2005). The influence of writing practice on letter recognition in preschool children: A comparison between handwriting and typing. Acta Psychologica, 119(1), 67-79. https://doi.org/10.1016/j.actpsy.2004.10.019.

Lundetræ, K., Solheim, O. J., Schwippert. K., \& Uppstad, P. H. (2017). Protocol: 'On Track', a grouprandomized controlled trial of an early reading intervention. International fournal of Educational Research, 86, 87-95. https://doi.org/10.1016/j.ijer.2017.08.011

Martin, J. R., \& Rose, D. (2008). Genre relations: Mapping culture. Equinox eBooks Publishing.

Mangen, A., Anda, L., Oxborough, G., \& Brønnick, K. (2015). Handwriting versus keyboard writing: Effect on word recall. Fournal of Writing Research, 7, 227-247. https://doi.org/10.17239/jowr-2015.07.02.1

Mangen, A., \& Velay, J.-L. (2010). Digitizing literacy: Reflections on the haptics of writing. In M. H. Zadeh (Ed.), Advances in haptics (pp. 385-402). INTECH web.

Miller, B., McCardle, P., \& Long, R. (2012). The reading-writing connection. International Reading Association.

Ministry of Education and Research. (2006). Lereplan Kunnskapsløftet. Utdanningsdirektoratet.

Ministry of Education and Research. (2019). Lareplan Kunnskapsløftet 2020. Utdanningsdirektoratet. https:// www.udir.no/lk20/nor01-06/kompetansemaal-og-vurdering/kv116

Norwegian Directorate for Education and Training. (2018). Utdanningsspeilet 2018:Tall og analyse av barnehager og grunnopplaringen $i$ Norge [Statistics]. Utdanningsdirektoratet. https://www.udir.no/utdanningsspeilet2018

Pakarinen, E., Lerkkanen, M.-K., Poikkeus, A.-M., Rasku-Puttonen, H., Eskelä-Haapanen, S., Siekkinen, M., \& Nurmi, J.-E. (2017). Associations among teacher-child interactions, teacher curriculum emphases and reading skills in Grade 1. Early Education and Development, 28(7), 858-879. https://doi.org/10.1080/1040 9289.2017.1289768

Pianta, R. C., La Paro, K. M., \& Hamre, B. K. (2008). Classroom Assessment Scoring System. Manual K-3. Teachstone Training, LLC.

Rosseel,Y. (2012). Lavaan: An R package for structural equation modeling. Fournal of Statistical Software, 48(2), 1-36. http://www.jstatsoft.org/v48/i02/

Seymore, P. H., Aro, M., \& Erskine, J. M. (2003). Foundation literacy acquisition in European orthographies. British fournal of Psychology, 94(2), 143-174. https://doi.org/10.1348/000712603321661859 


\section{Study protocol}

Simpson, S., Nottbusch, G., \& Torrance, M. (2017). OpenHandWrite (Version 0.3.2) [Computer software]. https:/github.com/isolver/OpenHandWrite/releases/tag/v0.3.2-beta

Solheim, O. J., Rege, M., \& McTigue, E. (2017). Study protocol: "Two Teachers": A randomized controlled trial investigating individual and complementary effects of teacher-student ratio in literacy instruction and professional development for teachers. International fournal of Educational Research, 86, 122-130. https:// doi.org/10.1016/j.ijer.2017.09.002

Solheim, O. J., Frijters, J. C., Lundetræ, K., \& Uppstad, P. H. (2018). Effectiveness of an early reading intervention in a semi-transparent orthography: A group randomised controlled trial. Learning and Instruction, 58, 65-79. https://doi.org/10.1016/j.learninstruc.2018.05.004

Spilling, E. F., Rønneberg, V., Rogne, W. M., \& Torrance, M. (in progress). Written composition of school starters predictors of quality in narratives written by hand and by keyboard.

Størksen, I., Ellingsen, I. T., Tvedt, M. S., \& Idsøe, E. M. (2013). Norsk vokabulartest (NVT) for barn i overgangen mellom barnehage og skole: Psykometrisk vurdering av en nettbasert test. Spesialpedagogikks Forskningsdel, 4(13), 40-54.

Sunde, K., \& Lundetræ, K. (2019). Is a faster pace of letter instruction associated with other teaching practices? Nordic Fournal of Literacy Research, 5(2). https://doi.org/10.23865/njlr.v5.1668

Torgesen, J. K., Wagner, R. K., \& Rashotte, C. A. (1999). TOWRE: Test of word reading efficiency. Psychological Corporation.

Van Dijk, T. A., \& Kintsch, W. (1983). Strategies of discourse comprehension. Academic Press.

Velay, J. L., \& Longcamp, M. (2013). Motor skills and written language perception: Contribution of writing knowledge to visual recognition of graphic shapes. In Y. Coello, \& A. Bartolo (Eds.), Language and action in cognitive neuroscience (pp. 161-176). Psychology Press.

Vygotsky, L. S. (1962). Thought and language. The Massachusetts Institute of Technology Press.

Wechsler, D. (1991). WISC-III: Wechsler intelligence scale for children: Manual. Psychological Corporation.

Wollscheid, S., Sjaastad, J., \& Tømte, C. (2016). The impact of digital devices vs. Pen(cil) and paper on primary school students' writing skills: A research review. Computers $\mathcal{E}$ Education, 95, 19-35. https://doi. org/10.1016/j.compedu.2015.12.001 